\title{
Mengungkap Realitas Kepatuhan Wajib Pajak Pasca Tax Amnesty
}

\author{
Sulistiowati ${ }^{1,}$ Syaiful ${ }^{2 *}$ \\ ${ }^{1,2}$ Universitas Muhammadiyah Gresik,
}

\begin{abstract}
This study aims to uncover and interpret the taxpayer compliance after tax amnesty from the point of view of individual taxpayers and tax consultants. The study was conducted using qualitative research methods, with an interpretive paradigm. Data sources are primary data obtained from the results of in-depth interviews with several informants who met the criteria in this study. The results of this study are that taxpayers interpret compliance after tax amnesty as a mathematical tariff to make amends in tax reporting. Tax amnesty is a golden opportunity to avoid tax surveillance and inspection. Tax consultants interpret compliance after tax amnesty as a dilemma experienced by taxpayers due to elements of compulsion and fear of regulatory threats. Tax amnesty does not automatically increase taxpayer compliance. Indonesia can create voluntary compliance if the government changes the definition of tax to become a direct contravention and in contact with the activities of people's daily lives.
\end{abstract}

Keywords: Tax Amnesty, Tax compliance, Voluntary Compliance

Tipe artikel: qualitative - intrepetive paradigm

\section{Pendahuluan}

\subsection{Latar Belakang Masalah}

Pajak dapat dikatakan sebagai jantung dari perekonomian Indonesia. Data Kementerian Keuangan Republik Indonesia, mencatat bahwa sebesar Rp 1.489,9 triliun kontribusi pajak terhadap APBN 2017. Data ini menunjukkan pajak menjadi penyumbang terbesar APBN dengan kontribusi sekitar 85,6\% dari total pendapatan negara. Dalam mengoptimalkan penerimaan negara terutama dari sektor pajak, pemerintah telah melakukan modernisasi dan reformasi pajak. Pada tahun 1984, Indonesia melalui reformasi pajak mengimplementasikan Self Assesment System. Dalam Self Assesment System ini, wajib pajak diberi hak dalam mendaftar, menghitung, membayar, serta melaporkan sendiri jumlah pajak terutangnya sesuai dengan ketentuan perpajakan yang berlaku. Dengan adanya Self Assesment System ini bertujuan agar hubungan yang terjalin antara Direktorat Jenderal Pajak (DJP) dengan wajib pajak (WP) menjadi baik sehingga kesadaran dari WP untuk patuh dalam memenuhi kewajiban perpajakannya semakin meningkat. Namun, Self Assesment System menemui banyak kendala. Seperti yang diungkapkan dalam penelitian Diamastuti (2012) bahwa Self Assesment System menyebabkan munculnya beberapa perilaku negatif seperti: tax avoidance (penghindaran pajak), tax evasion (perlawanan pajak) dan tax arrearage (penundaan pemenuhan kewajiban perpajakan).

\footnotetext{
${ }^{*}$ Penulis yang sesuai:

E-mail: syaiful@umg.ac.id

Afiliasi: Universitas Muhammadiyah Gresik
} 
Selain penerapan Self Assesment System, upaya pemerintah terhadap reformasi pajak yang digadanggadang sebagai momentum untuk meningkatkan kepatuhan wajib pajak yang diluncurkan baru-baru ini adalah implementasi kebijakan pengampunan pajak atau lebih dikenal dengan istilah tax amnesty. Masih rendahnya tingkat kepatuhan wajib pajak menjadi salah satu alasan dilakukannya reformasi

pajak. Program yang diwujudkan dalam Undang-Undang RI no. 11 tahun 2016 ini telah menjadi program nasional yang pelaksanaan dan pengawasannya langsung di pimpin oleh Bapak Presiden Republik Indonesia yaitu Joko Widodo. Dengan munculnya kebijakan tax amnesty, pemerintah berharap mendapatkan solusi terhadap permasalahan yang ada yaitu kepatuhan wajib pajak yang dapat di redam sehingga WP tergerak untuk lebih patuh dan berpartisipasi secara sukarela. Namun, faktanya kebijakan ini masih belum dapat dijadikan senjata untuk meningkatkan kepatuhan wajib pajak. Menurut penelitian yang dilakukan Ngadiman dan Huslin (2015) mengenai pengaruh sunset policy, tax amnesty, dan sanksi pajak terhadap kepatuhan wajib pajak. Hasil dari penelitian tersebut adalah tax amnesty berpengaruh positif terhadap kepatuhan wajib pajak. Dapat disimpulkan, bahwa dengan adanya kebijakan tax amnesty menjadi strategi jitu dalam meningkatkan angka kepatuhan wajib pajak. Akan tetapi penelitian tersebut dilakukan kurang lebih satu tahun sebelum kebijakan tax amnesty dijalankan, yakni di tahun 2015. Sedangkan kebijakan tax amnesty diberlakukan secara resmi pada 1 Juni 2016. Sehingga, penelitian tersebut tidak menggambarkan realita kebijakan tax amnesty yang sudah berjalan sampai saat ini.

Sejak awal munculnya amnesty pajak sudah banyak menuai pro dan kontra. Bagi yang mendukung program ini, mereka beranggapan rasa aman dan tidak perlu takut dari kejaran petugas pajak karena semua kewajiban perpajakannya dianggap sudah sah. Selain itu, sebagai bentuk terobosan kebijakan untuk mendorong repatriasi akibat banyaknya dana WP Indonesia yang terparkir di luar negeri. Sedangkan bagi yang tidak mendukung program ini, menganggap para pelaku pajak justru mendapatkan fasilitas dan perlakuan khusus yang dirasakan tidak adil bagi WP yang membayar pajak secara patuh. Menurut penelitian yang dilakukan Bagiyada \& Darmayasa (2016) bahwa rendahnya tingkat kepatuhan wajib pajak, banyaknya dana yang terparkir di luar negeri serta buruknya database perpajakan nasional yang membutuhkan langkah khusus untuk melakukan reformasi sistem perpajakan nasional. Indonesia pernah menerapkan kebijakan tax amnesty pada tahun 1964 dan 1984. Pada saat itu penerapan kebijakan tax amnesty mengalami kegagalan. Berdasarkan hasil penelitian Ragimun (2015) menyatakan bahwa kegagalan kebijakan tax amnesty pada waktu itu disebabkan oleh WP yang kurang respons serta tidak didukung oleh sarana dan prasarana. Sedangkan hasil penelitian Tambunan (2015) menambahkan bahwa tidak adanya law enforcement yang tegas pasca tax amnesty menjadi pemicu kegagalan atas diterapkannya kebijakan ini. Indonesia tentunya harus belajar dari kegagalan yang pernah dialami sebelumnya dalam penerapan tax amnesty .

Kepatuhan wajib pajak menjadi hal yang menarik untuk dikaji. Rendahnya kepatuhan wajib pajak di nilai menjadi masalah klasik dalam perpajakan Indonesia. Di sisi lain, upaya pemerintah yang ditunjukkan melalui tax amnesty digadanggadang masih belum menunjukkan perubahan perilaku kepatuhan wajib pajak secara signifikan. Hal ini dilihat dari tingkat partisipasi wajib pajak dinilai masih rendah. Berdasarkan data dari primadhyta (2017) Sampai berakhirnya periode tax amnesty, tercatat sejumlah 956 ribu WP yang mengikuti tax amnesty. Jumlah ini hanya 2,9\% dari jumlah WP yang memiliki NPWP ( Nomor Pokok Wajib Pajak ) atau sekitar 4,8\% dari WP yang menyampaikan SPT. Angka ini menunjukkan program tax amnesty yang dicanangkan pemerintah tidak mencapai target atau masih jauh dari ekspektasi. Selain itu, hasil tax amnesty juga dinilai tidak mencapai angka yang di harapkan. Menurut Kusuma (2017) hasil amnesty pajak dinilai belum memuaskan dikarenakan target repatriasi 1.000 triliun hanya tercapai 147 triliun, target uang tebusan 165 triliun realisasiya hanya 135 triliun. Hal inilah yang membuat beberapa kalangan pengamat menilai bahwa tax amnesty gagal. Hasil itu juga menambah rentetan tidak maksimalnya target-target yang dicanangkan oleh Direktorat Jenderal Pajak (DJP). Pada September lalu, pemerintah meluncurkan regulasi khusus sebagai tindak lanjut kebijakan pengampunan pajak. Regulasi turunan dari UU no. 11 tahun 2016 tertuang dalam PP 36 tahun 2017 yang diisukan sebagai wujud keadilan bagi WP yang mengikuti tax amnesty. Namun, pelaku usaha memandang hal kebijakan tersebut akan berpotensi melemahkan kepatuhan pajak. Meskipun program tax amnesty telah usai, bukan berarti WP terbebas dari penegakan hukum. Karena WP masih harus 
mempertanggungjawabkan harta yang dilaporkan sebagai bentuk konsekuensi dari Surat Pernyataan Harta (SPH) yang dilaporkan pada saat mengikuti tax amnesty.

\subsection{Rumusan Masalah}

Berdasarkan uraian dari latar belakang di atas, maka rumusan masalah dalam penelitian ini adalah : Bagaimana memaknai kepatuhan wajib pajak pasca tax amnesty dalam perspektif konsultan dan wajib pajak?

\subsection{Tujuan Penelitian}

Berdasarkan pada rumusan masalah yang telah disebutkan di atas, maka penelitian ini bertujuan untuk mengungkap dan menjelaskan makna kepatuhan wajib pajak pasca tax amnesty menurut perspektif konsultan pajak dan wajib pajak.

\section{Tinjuan Pustaka}

\subsection{Studi Fenomenologi}

Fenomenologi berasal dari kata Yunani phainomenon yang mempunyai arti fenomena atau yang menampak diri (Hasbiansyah, 2008). Dalam bahasa Indonesia dikenal dengan istilah gejala. Fenomena adalah fakta yang disadari dan masuk ke dalam akal manusia. Sehingga, suatu objek ada dalam relasi kesadaran. Fenomenologi merupakan suatu metodologi dalam pendekatan penelitian yang bersifat kualitatif. Dalam fenomenologi tidak ada teori, tidak ada hipotesis, dan tidak ada sistem (Brower dalam Hasbiansyah, 2008).

Mulanya fenomenologi dikenalkan oleh Johann Heinrick Lambert, sedangkan pelopor yang dikenal sebagai Bapak fenomenologi adalah Edmund Husserl. Edmund Husserl dilahirkan di sebuah kota kecil Prosznitz di daerah

Moravia tahun 1859 dari keluarga penganut yahudi. Pada tahun 1881 setelah Husserl berhasil meraih gelar doktoralnya, Husserl berkenalan dengan Prof.Franz Brentano yakni seseorang yang sangat berpengaruh dalam pemikiran Husserl terutama berkaitan dengan metode fenomenologinya. Fenomenologi dikenal sebagai salah satu cabang filsafat. Edmund Husserl secara intens menggunakan fenomenologi sebagai kajian filsafat yang kemudian menjadi metodologi penelitian, pertama kali pada tahun 1859-1938.

Menurut Kamayanti (2016:153) dalam menganalisis hasil penelitian menggunakan fenomenologi transedental, peneliti dapat melakukan analisis data dengan mengidentifikasi lima unsur yang meliputi noema, epoche/bracketing, noesis, intentional analysis, dan eidetic reduction. Peneliti melakukan analisis secara responsif terhadap tanggapan informan atas suatu pertanyaan. Peneliti menangkap apa yang tampak (noema). Berdasarkan noema, peneliti kemudian melakukan bracketing yakni menyibak apa yang ada di balik noema tersebut. Kemudian, peneliti dapat memperoleh noesis atau makna yang lebih mendalam dari noema. Langkah selanjutnya peneliti dapat memahami bagaimana noesis membentuk noema. Langkah ini disebut intentional analysis. Intentional analysis merupakan pemahaman peneliti terkait bagaimana proses bracketing dapat mengungkap bagaimana noesis membentuk noema. Setelah keseluruhan unsur terpenuhi, maka selanjutnya peneliti dapat memperoleh penggabungan dari keseluruhan proses tersebut, yaitu eidetic reduction. Proses penting dari fenomenologi terletak pada bracketing oleh peneliti. Kemampuan peneliti dalam menyikapi tanggapan informan akan menentukan sejauh mana kedalaman penggalian data. Fenomenolog dinyatakan sudah mencapai kesadaran terdalam apabila sudah mencapai titik jenuh atau lebih tepatnya tidak ditemukan bracketing baru.

\subsection{Tax Amnesty}

Tax Amnesty atau dikenal dengan pengampunan pajak menurut UU No.11 Tahun 2016 merupakan kebijakan penghapusan pajak yang seharusnya terutang, tidak dikenai sanksi administrasi perpajakan dan sanksi pidana di bidang perpajakan, dengan cara mengungkap harta dan membayar uang tebusan. 
Uang tebusan yang dimaksud adalah uang yang dibayarkan oleh wajib pajak kepada negara untuk memperoleh pengampunan pajak. Dalam penelitian Ragimun (2016) menjelaskan definisi pengampunan pajak adalah suatu kelonggaran yang diberikan kepada wajib pajak untuk membayar pajak dalam jumlah tertentu dan dalam kurun waktu yang terbatas yakni pengampunan dalam kewajiban perpajakan meliputi bunga dan denda yang berkaitan dengan masa pajak sebelumnya atau periode tertentu tanpa takut hukuman pidana. Menurut Sakti dan Hidayat (2016:6) bahwa tujuan diimplementasikannya tax amnesty dapat dilihat dari dua sisi, yang pertama dari sisi perpajakan yakni sebagai upaya pemerintah dalam menghimpun penerimaan negara baik itu harta dalam negeri maupun luar negeri yang selama ini belum terungkap. Sehingga memperluas basis data perpajakan. Kedua, ditinjau dari sisi perekonomian dapat meningkatkan penerimaan negara terutama dari sektor pajak. Hal ini tentu berdampak pada berkurangnya angka pengangguran maupun kemiskinan, membaiknya nilai tukar rupiah dan nilai investasi di Indonesia.

\subsection{Kepatuhan Wajib Pajak}

Dalam Peraturan Menteri Keuangan Nomor 192/PMK.03/2007 bahwa seorang wajib pajak yang dikatakan memiliki kepatuhan pajak apabila memenuhi kriteria berikut yaitu pertama apabila tepat waktu dalam menyampaikan SPT. Kedua, tidak memiliki tunggakan pajak untuk semua jenis pajak kecuali apabila telah memperoleh izin untuk melakukan angsuran atau penundaan pembayaran pajak. Ketiga, laporan keuangan diaudit oleh auditor independen atau lembaga pemerintah yang berwenang melakukan pengawasan keuangan dan memperoleh pendapat wajar tanpa pengecualian selama tiga tahun berturut- turut. Keempat, tidak pernah mendapatkan pidana karena melakukan tindak pidana di bidang perpajakan dan sudah ditetapkan oleh putusan pengadilan serta memiliki kekuatan hukum tetap selama lima tahun terakhir. Menurut Rahayu (dalam Huslin, 2015) mendefinisikan kepatuhan pajak sebagai kondisi di mana wajib pajak memenuhi semua kewajiban pajaknya serta melaksanakan hak pajaknya. Ada dua macam kepatuhan pajak, yaitu kepatuhan formal dan kepatuhan material. Kepatuhan formal adalah suatu keadaan di mana wajib pajak dapat memenuhi kewajiban perpajakan secara formal dengan ketentuan yang ada di dalam undang-undang perpajakan. Kepatuhan material suatu keadaan di mana wajib pajak secara substantif sudah memenuhi ketentuan yang ada dalam undang-undang perpajakan.

\section{Metode Penelitian}

\subsection{Pendekatan penelitian}

Dalam Penelitian ini, peneliti berupaya untuk memahami, mengungkap serta memaknai suatu fenomena tentang kepatuhan wajib pajak pasca tax amnesty dari sudut pandang informan. Tujuan penelitian akan menentukan cara pandang terhadap sesuatu yang disebut paradigma. Paradigma merupakan cara peneliti memosisikan diri tentang realita atau kebenaran ilmu yang ingin dicapai peneliti (Kamayanti, 2016:13). Dalam penelitian ini, paradigma penelitian yang digunakan adalah paradigma interpretif. Menurut Kamayanti (2016:21) Paradigma interpretif merupakan cara pandang yang bertujuan untuk memahami secara mendalam tentang mengapa realita itu terjadi.

Pada penelitian ini, metodologi yang digunakan adalah fenomenologi. Dalam hal ini, fenomenologi digunakan sebagai alat analisis untuk mempelajari dan memahami bagaimana subjek penelitian memaknai kebijakan tax amnesty sebagai upaya peningkatan kepatuhan wajib pajak. Fenomenologi yang digunakan dalam penelitian ini adalah fenomenologi transendental. Fenomenologi transendental adalah studi yang memusatkan perhatian pada kesadaran. Sebagai upaya untuk mencapai pemahaman yang mendalam, penelitian ini menggunakan pendekatan kualitatif. Menurut Moleong (2005:5) bahwa penelitian kualitatif merupakan penelitian dengan mengembangkan data-data yang ada secara deskriptif menggunakan kalimat-kalimat untuk menginterpretasikan makna terkait suatu fenomena yang dialami oleh subjek.

\subsection{Lokasi Penelitian}

Lokasi penelitian dilakukan di wilayah Gresik. Masing-masing informan yaitu konsultan pajak dan wajib pajak dilakukan di lokasi perusahaan tempat informan bekerja.

\subsection{Subjek Penelitian}


Dalam penelitian dengan pendekatan kualitatif dibutuhkan data dari seorang yang disebut informan. Informan dalam penelitian ini adalah konsultan pajak dan wajib pajak orang pribadi. Pemilihan informan penelitian didasarkan pada pengalaman subjek mengenai fenomena yang sedang diteliti. Keduanya merupakan subjek yang paling representatif untuk mengungkap bagaimana kepatuhan pasca tax amnesty. Alasan dari pemilihan informan tersebut karena konsultan pajak adalah subjek yang memiliki pengetahuan, keahlian, sekaligus sebagai pengamat isu-isu perpajakan yang sedang terjadi. Sedangkan untuk wajib pajak ialah wajib pajak orang pribadi yang telah mengikuti tax amnesty.

\subsection{Sumber dan Jenis Data}

Jenis data penelitian dalam penelitian ini menggunakan jenis data subjek berupa opini, sikap, pengalaman, atau karakteristik seseorang atau sekelompok orang yang menjadi subjek penelitian (informan). Menurut Sujarweni (2015 : 35) sumber data dibagi menjadi dua yaitu sumber data primer dan sekunder. Sumber data primer mengandung arti bahwa data diperoleh secara langsung dari sumbernya, misalnya pendapat subjek tentang sesuatu. Data dalam penelitian ini didapat dari sumber data secara langsung, yakni informan atau subjek penelitian. Jadi, dapat disimpulkan bahwa sumber data dalam penelitian ini merupakan sumber data primer.

\subsection{Metode pengumpulan Data}

Teknik pengumpulan data dalam penelitian ini adalah dengan melakukan in depth interview (wawancara mendalam). Wawancara dilakukan secara tidak terstruktur. Mekanisme dan teknis wawancara akan berkembang sesuai dengan keadaan saat penelitian berlangsung. Jadi, peneliti hanya menyiapkan pedoman wawancara yang sederhana, yakni poin-poin kunci yang nantinya akan dikembangkan dalam pertanyaan.

3.6 Unit Analisis

Dalam penelitian ini, peneliti menggunakan unit analisis persepsi, sikap, dan perilaku yang dimiliki konsultan dan wajib pajak dalam menjalankan perannya terkait tax amnesty. Penentuan unit analisis ini didasarkan pada beberapa persepsi, sikap, dan perilaku yang akan menentukan bagaimana tanggapan informan mengenai implementasi kebijakan tax amnesty.

\subsection{Analisis Data}

Analisis data yang digunakan pada penelitian ini mengacu pada modifikasi terhadap metode Stevick, Colaizzi, dan Keen dalam Harbiansyah (2008) yang terbagi menjadi lima tahap analisis data sebagai berikut :

1. Deskripsi tentang pengalaman terhadap fenomena

Tahap awal dari penelitian yang dilakukan peneliti yaitu berusaha untuk mendeskripsikan gambaran menyeluruh fenomena kepatuhan wajib pajak dalam hal ini yang berkaitan dengan kebijakan tax amnesty. Hal ini dilakukan peneliti agar dapat menyingkirkan pengalaman pribadi peneliti terkait tax amnesty sehingga fokus penelitian ada pada informan penelitian.

2. Tahap Horizonalization (membuat daftar pernyataan)

Peneliti membuat daftar pernyataan-pernyataan penting yang relevan dengan topik yaitu kepatuhan wajib pajak pasca tax amnesty. Pada tahap ini, peneliti harus bersabar untuk menunda penilaian (bracketing/epoche); artinya, unsur subjektivitasnya jangan mencampuri upaya merinci poin-poin penting, sebagai data penelitian, yang diperoleh dari hasil wawancara. Pernyataan-pernyataan yang tidak sesuai dengan topik akan di hilangkan.

3. Tahap Cluster of Meaning

Pengklasifikasian pernyataan-pernyataan yang sudah dirumuskan peneliti ke dalam tema-tema atau unit-unit makna, serta menyisihkan pertanyaan yang tumpang tindih atau berulang-ulang. Pada tahap ini dilakukan : (a) Textural Description (deskripsi tekstural): peneliti menuliskan apa yang dialami oleh informan berkaitan dengan kebijakan tax amnesty; (b) Structural Description (deskripsi struktural) : Peneliti menjelaskan bagaimana fenomena kepatuhan wajib pajak itu dialami oleh para informan. Peneliti juga mencari berbagai makna kepatuhan wajib pajak berdasarkan refleksi si peneliti sendiri, baik itu berupa opini, penilaian, perasaan, maupun harapan informan tentang kepatuhan wajib pajak pasca tax amnesty.

4. Deskripsi esensi

Peneliti kemudian memberikan penjelasan secara naratif mengenai esensi dari makna kepatuhan wajib pajak pasca tax amnesty yang diteliti dan mendapatkan makna pengalaman informan terkait kebijakan tax amnesty tersebut. 
5. Pelaporan hasil penelitian

Memberikan pemahaman kepada pembaca tentang bagaimana seseorang mengalami suatu kepatuhan setelah berakhirnya kebijakan tax amnesty. Namun, Dalam menginterprestasikan data pada laporan hasil penelitian, maka peneliti menggunakan kertas kerja analisis fenomenologi yang dikembangkan oleh Kamayanti (2016 : 157). Penggunaan kertas kerja ini ditujukan agar analisis data penelitian menjadi lebih mudah pemetaannya.

Peneliti melakukan klasifikasi pada masing-masing unsur fenomenologi. Unsur-unsur fenomenologi menurut Kamayanti (2016 : 158) dibagi menjadi lima unsur yaitu sebagai berikut :

1. Noema, merupakan istilah dalam fenomenologi yang merujuk pada kesadaran yang tampak.

2. Epoche, pemusatan telaah pada temuan tertentu untuk kemudian dikupas lebih mendalam mengapa temuan tersebut terjadi.

3. Noesis, kesadaran yang muncul akibat pengalaman karena dan pada waktu dan tempat tertentu.

4. Intentional Analysis, telaah bagaimana noesis membentuk noema alasan mengapa suatu aksi/perilaku terjadi.

5. Eidetic Reduction, proses dalam fenomenologi yang mengungkapkan hasil sebuah kondensasi dari seluruh proses pemaknaan; atau ide yang melandasi keseluruhan kesadaran murni tersebut.

Penelitian ini dilakukan untuk mengetahui bagaimana persepsi para informan mengenai kepatuhan wajib pajak setelah berakhirnya program tax amnesty. Langkah-langkah yang peneliti lakukan untuk memperoleh data dan mengungkap kepatuhan wajib pajak pasca tax amnesty adalah sebagai berikut:

1. Peneliti mempelajari fenomena kepatuhan wajib pajak dengan segala permasalahannya melalui survey/observasi.

2. Menentukan informan (konsultan pajak dan WP OP yang mengikuti tax amnesty) yang akan terlibat langsung dalam membantu proses penelitian.

3. Membuat rumusan pertanyaan untuk diberikan kepada informan agar jawaban yang diberikan oleh informan lebih terarah dan dapat menjawab permasalahan dalam penelitian.

4. Melakukan wawancara kepada informan sesuai dengan draft pertanyaan agar lebih terkonsep.

5. Mengumpulkan dan mengolah data sesuai dengan kategori informan.

6. Membuat pembahasan dan memberikan kesimpulan dari hasil penelitian yang telah dilakukan.

3.8 Pengujian Kredibilitas Data

Menurut Moleong (2005 : 324) ada empat kriteria keabsahan data dalam penelitian kualitatif. Empat kriteria tersebut adalah derajat kepercayaan (credibility), keteralihan (transferability), kebergantungan (dependenability), dan kepastian (confirmability).

Kredibilitas data bertujuan untuk membuktikan apakah yang sudah teramati oleh peneliti sudah sesuai dengan apa yang sebenarnya ada dalam dunia kenyataan. Trianggulasi dalam penelitian ini dilakukan dengan beberapa cara. Pertama, penelitian ini menggunakan alat analisis fenomenologi, maka peneliti harus melakukan pemeriksaan ulang terkait konsistensi jawaban informan. Pemeriksaan ini bertujuan untuk mengetahui apakah data penelitian dapat dipercaya (reliabel). Selain itu, peneliti juga menggunakan teknik pembandingan antara hasil penelitian terdahulu dengan data yang didapatkan dari hasil wawancara (triangulasi peneliti). Tahapan ini bertujuan untuk mendapatkan gambaran tentang makna kepatuhan wajib pajak yang telah diamati dalam penelitian sebelumnya dibandingkan dengan data yang didapatkan peneliti dari hasil wawancara dengan informan.

\section{Hasil Penelitian Dan Interpretasi}

\subsection{Deskripsi Data Penelitian}

Metode pengumpulan data yang dilakukan dalam penelitian ini melalui proses wawancara langsung dengan informan, sehingga data yang diperoleh adalah data primer. Wawancara dilakukan secara mendalam dengan membuat draft pertanyaan kunci yang akan dijawab oleh informan. Proses wawancara dilakukan kepada dua informan yang dipilih peneliti sebagai subjek dalam penelitian. Informan tersebut dipilih dari latar belakang yang berbeda yakni wajib pajak orang pribadi yang mengikuti tax amnesty dan konsultan pajak. Kedua informan tentunya sangat erat kaitannya dengan topik yang diangkat yakni makna kepatuhan setelah berakhirnya kebijakan tax amnesty. Seorang informan yaitu ibu WF merupakan seorang wajib pajak yang mengikuti tax amnesty. Ibu WF berusia sekitar 30 tahun. Ibu WF merupakan wajib pajak yang berprofesi sebagai direktur disalah satu 
perusahaan swasta di daerah Gresik yang bergerak dibidang penyedia jasa angkutan pelayaran. Pada pelaksanaan tax amnesty, Ibu WF mengikuti tax amnesty periode pertama.

Dari latar belakang pendidikan, Ibu WF merupakan seorang sarjana di bidang Akuntansi dari perguruan tinggi ternama di Surabaya. Ibu WF juga merupakan seorang dosen mata kuliah perpajakan indonesia dan tax planning (Perencanaan Pajak) di Universitas Muhammadiyah Gresik. Hal ini yang menjadi alasan peneliti untuk memilih Ibu WF sebagai informan karena peneliti menganggap Ibu WF cukup memahami mekanisme perpajakan yang berlaku terutama mengenai kebijakan tax amnesty.

Pada hari yang sama yakni Senin, 24 April 2018 peneliti mendapatkan kabar yang cukup mendadak dari informan kedua yakni Bapak Heru untuk segera menemui beliau guna proses wawancara. Bapak Heru merupakan konsultan pajak dan praktisi pajak yang tergabung di tax center Universitas Muhammadiyah Gresik. Pada akhirnya, peneliti berkesempatan melakukan wawancara dengan Bapak Heru sesuai waktu dan tempat yang telah dikehendaki yakni di ruang konsultasi Fakultas Ekonomi dan Bisnis Universitas Airlangga Surabaya, di tempat Bapak Heru membagikan ilmunya. Pelaksanaan wawancara kurang lebih 55 menit. Hal ini mengingat terbatasnya waktu yang dimiliki oleh Bapak Heru.

\subsection{Analisis dan Penyajian Data}

Data hasil penelitian ini adalah data berupa rekaman hasil wawancara dengan informan. Penelitian kualitatif dengan menggunakan pendekatan fenomenologi tidak membutuhkan data sekunder. Hal ini karena perhatian dan fokus peneliti diarahkan pada pengalaman informan serta bagaimana informan tersebut memaknai pengalaman tersebut (Kamayanti, 2016; 151). Hal ini juga ditegaskan dengan teks "asumsi atas realitas berpusat pada "Aku" yang mengalami fenomena" (Kamayanti, 2016; 153). Oleh karena itu, peneliti hanya fokus untuk mengolah data hasil wawancara yang diperoleh dari perbincangan dengan informan.

Data hasil wawancara yang telah direkam melalui mesin perekam atau smart phone, kemudian direview (di dengarkan ulang). Tahapan selanjutnya adalah transkripsi hasil wawancara dengan informan. Setelah hasil wawancara ditranskripsikan, data direview kembali untuk mendapat pemahaman alur pembicaraan. Tidak berhenti di situ, proses reduksi data dilakukan dengan memilah dan memilih percakapan yang relevan dengan memberikan tanda kurung kurawal (...\{... ...) pada teks-teks percakapan tertentu.

Setelah Tahap Reduksi data selesai maka dilanjutkan dengan melakukan analisis data. Pada tahap ini peneliti mengklasifikasikan teks-teks pernyataan-pernyataan dan ungkapan-ungkapan informan yang dianggap relevan dengan topik yang diteliti ke dalam beberapa tema. Bagian ini disajikan pada lampiran hasil transkripsi dan deskripsi unsur-unsur fenomenologi (noema, epoche, noesis, intentional analysis, eidetic reduction). Tahap berikutnya ini adalah tahap deskripsi esensi yang dimuat pada bagian interprestasi atau analisis hasil penelitian. Hasil deskripsi esensi berbentuk uraian hasil wawancara penelitian dan dipadukan dengan interprestasi dari peneliti. Deskripsi esensi ditulis pada bagian isi analisis hasil penelitian. Tahapan akhir penelitian adalah menguji keabsahan data yang diperoleh dalam penelitian ini. Tahapan ini disebut juga dengan triangulasi data.

Adapun triangulasi yang digunakan dalam penelitian ini di antaranya :

1. Triangulasi Sumber

Peneliti melakukan uji keabsahan data dengan melakukan perbandingan antara keterangan informan satu dengan yang lain, yakni antara konsultan pajak dan wajib pajak yang telah mengikuti tax amnesty. Peneliti juga mengkonfirmasi jawaban dari hasil penelitian kepada masing-masing informan.

2. Triangulasi Peneliti

Peneliti melakukan perbandingan antara hasil penelitian sekarang dengan penelitian terdahulu. Peneliti menemukan beberapa kecocokan antara hasil penelitian sebelumnya dengan penelitian sekarang seperti contoh pada hasil penelitian Fidiana dan Istighfarin (2017) bahwa pelaksanaan sosialisasi tax amnesty masih kurang intensif dan tidak berkelanjutan. Hal ini bersesuaian dengan hasil wawancara peneliti dengan konsultan pajak bahwa meskipun sudah dilakukan sosialisasi tapi masih banyak wajib pajak yang tidak paham dengan kebijakan tax amnesty. Selain itu, peneliti juga melakukan pemeriksaan ulang atas konsistensi jawaban informan seperti contoh pada pertanyaan terkait keuntungan mengikuti tax amnesty. Jawaban Informan wajib pajak pertama kali menyebutkan bahwa "transaksi malah tunai" dan pada jawaban yang kedua menunjukkan bahwa "lari ke transaksi tunai". Peneliti mengajukan 
pertanyaan kepada wajib pajak dalam konteks yang sama namun dalam waktu yang berbeda mendapatkan hasil yang sama.

Berikut adalah cuplikan hasil wawancara peneliti dengan para informan, Peneliti memberikan pertanyaan yang sama kepada masing-masing informan, namun menghasilkan jawaban yang berbeda. Kode Kegiatan : S1/W1/24042018 (Ibu WF/Wajib Pajak)

Kode Kegiatan : S1/W2/24042018 (Bapak Heru/Konsultan Pajak)

Peneliti : Bagaimana respon wajib pajak (WP) dengan adanya program tax amnesty ini?

Ibu WF : Banyak pengusaha bilang itu mereka sejak adanya tax amnesty itu mereka bisa tidur. Bisa tidur pulas nyenyak. Ya karena itu dia tidak menutupi atau merahasiakan harta- hartanya yang ada di luar negeri.

Itu semua diungkap semua.

Bapak Heru : Hanya mereka euforia aja. Artinya wes ikut-ikutan. Supaya diarani ya patuh nggak dicap WP bandel atau WP sing gak patuh.

Peneliti : Menurut anda faktor apa yang mendorong wajib pajak untuk mengikuti tax amnesty?

Ibu WF : Banyak ampunan-ampunan kan kita kadang lalai lah. Ya ada beberapa yang dirasa belum ini kan nunggu moment itu. Moment itu kan enak kalau misalnya kalau memang ada TA lagi.

Bapak Heru : WP yang ikut TA itu karena faktor stressing, penekanan aturan. Adanya penekanan DJP yang dilakukan oleh KPP. DJP kan pusat, perangkat dilapangan kan KPP. KPP yang melakukan stressing menekan wajib pajak- wajib pajak supaya ikut TA. Kalau ndak ikut TA kalau ketahuan akan dikenakan sanksi toh 200 persen. Itu yang digaungkan. Sehingga mereka jadi takut jadi apa ya ketakutan tadi.

Peneliti : Bagaimana seharusnya untuk menumbuhkan kepatuhan sukarela pasca $\operatorname{tax}$ amnesty?

Ibu WF : Ya itu tadi susahnya karena persepi. Harus merubah itu. Buat masyarakat percaya dulu. Dengan cara memperbaiki internalnya maksudnya petugas pelaku fiskusnya tadi. Memberikan pelayanan yang lebih baik. Mereka bersikap lebih ramah tidak seperti menakuti. Kesannya kalau di datangi fiskus itu kadang ini mau ngapain nih. Kayak gitu-gitu kan.

Bapak Heru : Ya perlu effort dari kedua belah pihak. Tapi harusnya dari DJP

Berdasarkan hasil wawancara penelitian, peneliti menemukan adanya ungkapan-ungkapan tertentu yang "ditangkap" peneliti melalui proses epoche (meng-capture pernyataan atau ungkapan tertentu dan menelusurinya lebih dalam). Rincian dari hasil wawancara penelitian dengan informan wajib pajak yang mengikuti tax amnesty dan konsultan pajak tertuang pada bagian ini. Berikut adalah hasil wawancara penelitian dengan Ibu WF, dalam hal ini adalah wajib pajak yang ikut serta dalam tax amnesty.

Tabel 4.1

Hasil Wawancara Penelitian

Informan : Ibu WF (Wajib Pajak)

\begin{tabular}{|l|l|l|l|l|}
\hline Noema & Epoche & Noesis & Intentional Analysis & Eidetic Reduction \\
\hline
\end{tabular}




\begin{tabular}{|c|c|c|c|c|}
\hline $\begin{array}{l}\text { Sejak adanya tax } \\
\text { amnesty itu mereka } \\
\{\text { bisa tidur }\end{array}$ & $\begin{array}{l}\text { Dia \{tidak menutupi } \\
\text { atau merahasiakan\} } \\
\text { harta- hartanya yang } \\
\text { ada di luar negeri. }\end{array}$ & $\begin{array}{l}\text { Tarif pengenaan } \\
\text { pajaknya untuk } \\
\text { mengungkapkan } \\
\text { itu tadi \{tidak } \\
\text { berat\} saya rasa } \\
\text { dibanding dengan } \\
\text { hartanya yang } \\
\text { sekian besarnya }\end{array}$ & $\begin{array}{l}\text { Semua harta yang } \\
\text { disimpan di bank } \\
\text { khususnya bank ya } \\
\text { itu bisa \{diawasi\} } \\
\text { langsung. Jadi bisa } \\
\text { ketahuan }\end{array}$ & $\begin{array}{l}\text { Fasilitas untuk hibernasi : } \\
\text { Ibu WF merasa dengan } \\
\text { ikut TA, } \\
\text { harta yang telah diungkap } \\
\text { akan terhindar dari } \\
\text { pengawasan; tarif } \\
\text { pengenaan TA juga lebih } \\
\text { kecil dibandingkan dengan } \\
\text { total harta yang di ungkap. }\end{array}$ \\
\hline $\begin{array}{l}\text { Itu untuk } \\
\text { \{menghindari } \\
\text { pengawasan\}. }\end{array}$ & $\begin{array}{l}\text { transaksi } \\
\text { perbankan itu kan } \\
\{\text { kelihatan\} }\end{array}$ & $\begin{array}{l}\text { Banyak perusahaan } \\
\text { \{lari ke transaksi } \\
\text { tunai\}. }\end{array}$ & $\begin{array}{l}\text { Kalau buat } \\
\text { perusahaan ya } \\
\text { menguntungkan ya } \\
\text { karena bisa untuk } \\
\text { \{penggelapan pajak\} }\end{array}$ & $\begin{array}{l}\text { Kesempatan emas untuk } \\
\text { menghindari pengawasan : } \\
\text { Ibu WF merasa } \\
\text { diuntungkan setelah } \\
\text { mengikuti TA, hal itu } \\
\text { dibuktikan dengan } \\
\text { seringnya Ibu WF } \\
\text { menggunakan } \\
\text { transaksi tunai di } \\
\text { perusahaan sebagai } \\
\text { salah satu upaya } \\
\text { penggelapan pajak. }\end{array}$ \\
\hline $\begin{array}{l}\{\text { konsisten }\} ;\{\text { dibuat } \\
\text { percaya }\}\end{array}$ & $\begin{array}{l}\text { dikelola dengan } \\
\text { benar tidak untuk } \\
\text { \{disalahgunakan\} }\end{array}$ & $\begin{array}{l}\text { Aspek ekonomi } \\
\text { dan sosial itu dia } \\
\text { harus }\{\text { seimbang\} } \\
\text { sejalan }\end{array}$ & $\begin{array}{l}\text { nyata } \\
\text { peruntukannya }\end{array}$ & $\begin{array}{l}\text { Ibu WF menganggap } \\
\text { bahwa WP patuh mestinya } \\
\text { konsisten dalam } \\
\text { pelaporan pajaknya, selain } \\
\text { itu WP mestinya dibuat } \\
\text { percaya terhadap pajak } \\
\text { yang dibayarkan ke negara } \\
\text { dengan melihat sisi } \\
\text { ekonomi dan sosial yang } \\
\text { harus seimbang; Pajak } \\
\text { yang dibayarkan mestinya } \\
\text { digunakan untuk hal-hal } \\
\text { yang nyata. }\end{array}$ \\
\hline
\end{tabular}

Wawancara dengan Ibu WF berhasil memperoleh beberapa makna-makna penting yang "ditangkap" oleh peneliti. Seperti yang tercantum pada tabel di atas, peneliti berhasil menyibak bagaimana "Aku" dalam hal ini Ibu WF sebagai WP dalam memaknai keikutsertaannya pada program tax amnesty. Dari hasil tersebut, terungkap temuan secara tekstural (yang nampak) yakni " bisa tidur"; "menghindari pengawasan"; "konsisten"; "dibuat percaya". Peneliti dapat menyimpulkan bahwa pasca tax amnesty Ibu WF merasa aman karena telah diberikan kesempatan untuk melaporkan kewajiban harta maupun utang yang selama ini disembunyikan. Tarif tebusannya pun dirasa tidak memberatkan karena Ibu WF menganggap nilai dari uang tebusan tidaklah besar dibandingkan dengan total harta yang belum dilaporkan. Mengacu pada kesimpulan tersebut, peneliti kombinasikan dalam satu tema khusus yang mengupas kesadaran WP. Temuan tersebut dikemas dalam tema "Tax Amnesty : Sebuah Tarif Matematis Kepatuhan".

Selanjutnya, pada tabel 4.2 di bawah ini, terangkum poin-poin inti yang berhasil di ungkap oleh peneliti dari hasil wawancara dengan Bapak Heru, selaku konsultan pajak. berikut disajikan temuan hasil penelitian dari interaksi dengan Bapak Heru.

Tabel 4.2

Hasil Wawancara Penelitian Informan : Bapak Heru (Konsultan Pajak)

\begin{tabular}{|c|c|c|c|c|}
\hline Noema & Epoche & Noesis & $\begin{array}{c}\text { Intentional } \\
\text { Analysis }\end{array}$ & Eidetic Reduction \\
\hline
\end{tabular}




\begin{tabular}{|c|c|c|c|c|}
\hline $\begin{array}{l}\text { Karena faktor } \\
\text { \{stressing\}; } \\
\text { \{Euforia\} saja; } \\
\text { Artinya }\{\text { wes } \\
\text { ikutikutan\} }\end{array}$ & $\begin{array}{l}\text { Adanya } \\
\text { \{penekanan\} } \\
\text { aturan dari DJP } \\
\text { yang dilakukan } \\
\text { oleh KPP }\end{array}$ & $\begin{array}{l}\text { Sehingga mereka jadi } \\
\text { \{takut\} }\end{array}$ & $\begin{array}{l}\text { Kalau ndak ikut } \\
\text { TA kalau } \\
\text { ketahuan akan } \\
\text { \{dikenakan } \\
\text { sanksi\} toh } 200 \\
\text { persen. Itu yang } \\
\text { digaungkan. }\end{array}$ & $\begin{array}{l}\text { Bapak Heru menganggap bahwa } \\
\text { WP mengikuti TA faktor terbesarnya } \\
\text { adanya penekanan yang dilakukan } \\
\text { KPP. Penekanan yang dimaksud } \\
\text { adalah penekanan pada aturan } \\
\text { sehingga, WP menjadi takut } \\
\text { terutama pada sanksi atau denda } \\
\text { yang diberikan. }\end{array}$ \\
\hline $\begin{array}{l}\text { Pas final itu ya }\{ \\
\text { istilahe } \\
\text { penggantinya } \\
\text { TA\} lah. }\end{array}$ & $\begin{array}{l}\text { dikasih } \\
\text { \{kesempatan } \\
\text { sekali lagi\} }\end{array}$ & $\begin{array}{l}\text { Pasti ada yang } \\
\text { \{tidak dilaporkan\} }\end{array}$ & $\begin{array}{l}\text { Karena pajak } \\
\text { kembali ke } \\
\text { \{definisinya\}. } \\
\text { Pajak itu adalah } \\
\text { pungutan yang } \\
\text { sifatnya dipaksa. }\end{array}$ & $\begin{array}{l}\text { Bapak Heru memandang dengan } \\
\text { kebijakan baru pasca TA malah } \\
\text { melemahkan kepatuhan WP. WP } \\
\text { diberikan kesempatan kedua } \\
\text { kalinya untuk mengungkap } \\
\text { hartanya. Pada tataran ini " Aku" } \\
\text { (Bapak Heru) merasa bahwa Pas } \\
\text { final hanyalah istilah lain dari tax } \\
\text { amnesty. }\end{array}$ \\
\hline $\begin{array}{l}\text { DJP yang harus } \\
\text { \{membenahi }\}\end{array}$ & $\begin{array}{l}\text { kebijakan } \\
\text { \{tidak } \\
\text { membebani\} } \\
\text { masyarakat }\end{array}$ & $\begin{array}{l}\text { dikenai } \\
\text { pemajakan yang } \\
\text { \{sifatnya langsung\}. } \\
\text { Langsung } \\
\text { \{bersentuhan\} } \\
\text { dengan keseharian } \\
\text { dari masyarakat }\end{array}$ & $\begin{array}{l}\text { dalam rangka } \\
\text { untuk } \\
\text { \{transparansi\} }\end{array}$ & $\begin{array}{l}\text { Menurut Bapak Heru, untuk } \\
\text { menciptakan kepatuhan sukarela } \\
\text { terlebih dahulu DJP harus } \\
\text { berbenah. Kebijakankebijakan yang } \\
\text { dihasilkan harusnya lebih ramah } \\
\text { dan bersifat langsung. Kebijakan } \\
\text { seperti TA ini malah dianggap } \\
\text { semakin menambah beban } \\
\text { masyarakat. Jadi konsepnya harus } \\
\text { dirubah terutama dalam } \\
\text { mempertimbangkan } \\
\text { kontraprestasi langsung. " Aku } \\
\text { " disini merasa dengan pemajakan } \\
\text { yang langsung bersentuhan dengan } \\
\text { masyarakat akan merubah mindset } \\
\text { masyarakat yang selama ini pesimis } \\
\text { dengan pemerintah. }\end{array}$ \\
\hline
\end{tabular}

Sementara itu hasil wawancara dengan Bapak Heru selaku konsultan pajak (yang diposisikan sebagai pengamat dalam penelitian ini) berhasil memperoleh beberapa noema penting. Noema tersebut adalah "stressing"; "euforia"; "wes ikutikutan"; "istilahe penggantinya TA"; "membenahi". Kesimpulan yang dapat diambil dari noema tersebut adalah wajib pajak terdorong mengikuti tax amnesty hanya karena takut, sehingga patuhnya didasari oleh unsur keterpaksaan terhadap ancaman peraturan yang dilakukan oleh pemerintah. Bentuk ancaman tersebut meliputi sanksi maupun denda. Bapak Heru masih mempertanyakan efektivitas program tax amnesty dalam meningkatkan kepatuhan wajib pajak. Terlebih dalam mewujudkan suatu kepatuhan sukarela. Penelitian ini membagi noema-noema ini ke dalam dua tema analisis yakni " Tax Amnesty : Dilema antara Patuh dan Takut " serta "Kepatuhan dalam bingkai Sukarela".

\subsection{Interprestasi Hasil}

\subsubsection{Tax Amnesty: Sebuah Tarif Matematis Kepatuhan}

Pernyataan awal (noema) Ibu WF menyebut bahwa hadirnya tax amnesty membuat pengusaha \{bisa tidur\} dengan nyenyak dan pulas. Artinya pengusaha tidak perlu lagi takut dengan kejaran petugas pajak. Karena seluruh harta baik itu di dalam negeri maupun di luar negeri telah diungkap semua dengan kata lain \{tidak menutupi atau merahasiakan \} lagi harta ataupun utang yang dimiliki. Wajib pajak yang mengikuti tax amnesty mendapatkan keuntungan secara matematis. Pada titik ini kesadaran Ibu WF mengikuti tax amnesty karena adanya ketertarikan tarif yang dirasa \{tidak berat $\}$ dengan total harta yang di ungkapkan. Maksudnya adalah wajib pajak membandingkan jumlah uang yang akan dibayarkan atau dikenal dengan sebutan uang tebusan. Uang tebusan adalah sejumlah uang yang dibayarkan ke negara untuk memperoleh pengampunan pajak (Okfitasari,2016). Uang tebusan yang dibayar nilainya jauh lebih kecil dibandingkan dengan harta yang selama ini ditutup-tutupi oleh wajib pajak.Seperti pernyataan Ibu WF : "Iya jadi kesempatan. Nah kan tarif pengenaan pajaknya untuk mengungkapkan itu tadi tidak berat saya rasa di banding dengan hartanya yang sekian besarnya." 
Berdasarkan pendapat Ibu WF bahwa tarif tax amnesty itu nilainya kecil dibandingkan dengan total harta yang di ungkap. Momentum ini juga dijadikan sebagai ajang "pengakuan dosa" atas ketidakpatuhannya selama ini yakni kesalahan-kesalahan yang mungkin ada pada SPT 2015 ke bawah baik itu secara sengaja maupun tidak sengaja telah dilakukan oleh wajib pajak untuk menutupi atau merahasiakan harta yang dimiliki. Sehingga, dosa tersebut terampuni dengan mudah melalui keikutsertaan dalam kebijakan tax amnesty. Dalam hal ini "Aku" menyambut tax amnesty dengan rasa suka cita bukan karena keterpaksaan. Karena "Aku" merasa mendapatkan kemewahan dengan ampunan-ampunan pajak yang diberikan oleh pemerintah. Sehingga "Aku" sangat menyayangkan apabila kesempatan ini di sia-siakan. Wajib pajak harus melaporkan "total" atau "keseluruhan" harta ketika memutuskan untuk mengikuti tax amnesty. Wajib pajak tidak mengungkap informasi secara parsial pasca tax amnesty karena imbasnya akan lebih besar ketika DJP mengetahui informasi yang belum diungkap sepenuhnya oleh wajib pajak. Ibu WF merasa ketika ada aset yang belum dilaporkan akan mudah terdeteksi oleh petugas pajak. Seperti pernyataan Ibu WF :

"Sekarang ya OJK, Badan pengawas keuangan, itu sudah bekerja sama dengan semua bank. Jadi semua harta yang disimpan di bank khususnya bank ya itu bisa di awasi langsung. Jadi bisa ketahuan.“

Motivasi utama Ibu WF mengikuti tax amnesty yakni \{menghindari pengawasan\} dari petugas pajak, terutama transaksi-transaki yang berkaitan dengan perbankan. Pada tataran ini Ibu WF menyadari bahwa keikutsertaan dalam tax amnesty merupakan salah satu siasat wajib pajak dalam menghindari pengawasan. Di sini, “ Aku” merasa bahwa menghindari pengawasan adalah hal yang penting bagi wajib pajak. Seperti pernyataan Ibu WF bahwa transaksi perbankan itu kan \{kelihatan\}. Karena transaksinya mudah terlihat dengan adanya mutasi rekening yang dimiliki wajib pajak apabila dilakukan pemeriksaan. Adanya "kebebasan" dalam pemeriksaan pajak ini yang membuat wajib pajak tergiur untuk memanfaatkan program tax amnesty. Ketika pasca tax amnesty pengawasan semakin diperketat, wajib pajak tidak hanya diam. Menurut Penuturan Ibu WF banyak sekarang wajib pajak-wajib pajak yang memilih untuk menggunakan \{transaksi tunai\}. Karena sulit untuk dideteksi oleh petugas pajak. Tindakan ini digadang-gadang sebagai salah satu upaya \{penggelapan pajak\} yang menguntungkan bagi wajib pajak. karena bisa dilakukan transaksi tanpa PPN maupun PPh. Hal ini lah yang kemudian membuat perusahaan itu lebih memilahmilah antara menggunakan transaksi tunai atau transaksi bank. Berdasarkan uraian pertama dan kedua, peneliti menangkap bahwa pernyataan dan ungkapan Ibu WF bersesuaian. Sebagai wajib pajak, "Aku" (Ibu WF) merasa pengawasan maupun pemeriksaan adalah hal yang sangat meresahkan wajib pajak dan membuat wajib pajak cenderung takut. Peneliti juga menangkap makna tax amnesty berdasarkan ungkapan Ibu WF hanya sebagai fasilitas untuk terhindar dari pengawasan, bukan tentang subtansi tax amnesty itu sendiri. Namun, adanya keinginan dari "Aku" untuk memperbaiki diri ke depannya dengan bertindak untuk lebih patuh. Hal tersebut didukung dengan argumen \{konsisten\} dari Ibu WF setelah mengikuti tax amnesty, seperti konsisten dalam pelaporan SPT.

Peneliti menemukan sikap dari "Aku" yang kurang konsisten. Maksudnya, adanya sikap dari "Aku" yang masih mempertanyakan kebijakan tax amnesty kedepannya dan pengelolaan pajak yang timbul atas kepatuhannya selama ini. Di sini, peneliti menangkap kesadaran "Aku" berada pada titik kecemasan yang ditenangkan dengan pembenaran ingin patuh, meskipun kepatuhan tersebut tidak sepenuhnya. Karena masih ada hitung-hitungan tarif untuk mengikuti tax amnesty. Selain masalah besar kecilnya tarif yang dibayarkan, unsur harapan untuk menunggu lagi adanya tax amnesty yang ke sekian kalinya. Hal ini di dasari dengan fasilitas ampunan-ampunan yang diberikan kembali oleh pemerintah mengingat tax amnesty ini bukan pertama kalinya diterapkan di Indonesia.

Ibu WF menganggap bahwa sistem pajak di Indonesia masih butuh perbaikan-perbaikan. Terutama perbaikan pada lingkup internal pajak, seperti : pelayanan yang dilakukan fiskus kepada para wajib pajak. Namun, upaya dasar yang perlu dilakukan oleh pemerintah menurut pandangan Ibu WF yaitu menciptakan kondisi dimana wajib pajak \{dibuat percaya\} dengan pengelolaan pajak yang dibayarkan ke negara. Seperti pernyataan Ibu WF:

"Nah, jadi menciptakan suasana wajib pajak ini merasa percaya kan ada wajib pajak itu saya dengar percuma bayar pajak engko duweke di korupsi kan mereka gak percaya sama pemerintah. Percuma bayar pajak gede-gede. Akhire gak onok pembangunan sing signifikan gak onok perubahan. Indonesia kurang maju." 
Adanya sikap "traumatic" yang dimiliki wajib pajak terhadap pengelolaan pajak seperti korupsi besarbesaran yang dilakukan oleh petugas pajak. Hal ini yang memicu timbulnya kecemburuan antara pengawasan terhadap wajib pajak dan pengawasan terhadap petugas pajak sehingga muncul rasa ketidakadilan. Tujuan utama dilaksanakannya tax amnesty adalah meningkatkan penerimaan jangka panjang dan jangka pendek, meningkatkan database pembayar pajak, dan meningkatkan kepatuhan wajib pajak (Aneswari, 2016). Tax amnesty yang dianggap sebgai upaya dalam menstimulus kepatuhan wajib pajak justru masih membuat wajib pajak ketakutan terhadap pajak yang kemungkinan dapat \{disalahgunakan\} oleh oknum-oknum tertentu. Poin yang membuat wajib pajak patuh secara sukarela apabila aspek ekonomi maupun sosial dilakukan secara \{ seimbang\}. Maksudnya, kewajiban pajak yang dibayarkan ke negara itu \{nyata peruntukannya\} untuk kemakmuran rakyat. Sedangkan, Poin yang membuat wajib pajak tidak patuh adalah karena pemerintah hanya menuntut kewajiban pajak secara personal, namun tidak untuk hak. Maksudnya, kewajiban pajak berlaku secara personal kepada setiap individu yang memenuhi syarat subjektif dan objektif sebagai wajib pajak. Di lain pihak, wajib pajak tidak mendapatkan manfaat langsung atas kepatuhannya. Menurut Ibu WF, hal ini yang membuat wajib pajak enggan untuk membayar pajak.

\subsubsection{Tax Amnesty : Dilema Antara Patuh dan Takut}

Pada saat peneliti mewawancarai Bapak Heru yang merupakan konsultan pajak, dimana dalam hal ini diposisikan sebagai pengamat isu-isu perpajakan, peneliti sempat kaget mendengar ungkapan-ungkapan dari Bapak Heru. Bapak Heru mengungkap bahwa wajib pajak yang mengikuti tax amnesty di latarbelakangi karena mereka mengalami \{stressing\}, \{penekanan\}. Penekanan yang dimaksud adalah penekanan aturan yang dilakukan oleh Direktorat Jenderal pajak (DJP) melalui Kantor Pelayanan Pajak (KPP). Sehingga wajib pajak cenderung untuk \{takut\}.Wajib pajak yang mengikuti undang-undang pengampunan pajak tidak sepenuhnya memahami teknis secara memadai, tetapi wajib pajak cenderung mengalami ketakutan dan keterpaksaan (Okfitaasari, 2016). Bentuk ketakutan tersebut karena adanya ancaman \{dikenai sanksi \} atau denda 200 persen yang di berikan apabila wajib pajak diketahui selama ini belum melaporkan hartanya dari tahun 1985 sampai 2015 pada SPT tahunan. Berikut ungkapan Bapak Heru :

"WP yang ikut TA itu karena faktor stressing, penekanan aturan. Adanya penekanan DJP yang dilakukan oleh KPP. DJP kan pusat, perangkat dilapangan kan KPP. KPP yang melakukan stressing menekan wajib pajak- wajib pajak supaya ikut TA. Kalau ndak ikut TA kalau ketahuan akan dikenakan sanksi toh 200 persen. Itu yang digaungkan. Sehingga mereka jadi takut jadi apa ya ketakutan tadi."

Di sini terungkap bahwa partisipasi wajib pajak mengikuti tax amnesty adalah terpaksa patuh karena takut terhadap ancaman yang diberikan. Pada titik ini kesadaran "Aku" dalam memaknai kepatuhan adalah adanya ketakutan dari wajib pajak mengenai sanksi yang akan diberikan apabila tidak mengikuti tax amnesty dan terbukti ada harta yang masih belum dilaporkan. Realitas perbedaan antara takut dan patuh mengandung arti ketika tax amnesty dikorelasikan dengan upaya peningkatan kepatuhan wajib pajak. kepatuhan lebih mengarah kepada perilaku sadar wajib pajak. Lebih dari itu, wajib pajak yang patuh akan betul-betul memahami pentingnya pajak, dan berperilaku tertib dalam memenuhi kewajibannya secara sadar atau sukarela. Maka, ketakutan adalah hasil dari keterpaksaan sedangkan kepatuhan adalah hasil dari keikhlasan.

Menurut hasil penelitian Bagiayada dan Darmayasa (2016) Konsep hindu bali Catur Purusha Artha mencoba mendekontruksi konsep kebijakan pengampunan pajak. Dekontruksi konsep kebijakan tersebut diharapkan mampu mencerahkan hati seluruh wajib pajak demi meujudkan kepatuhan sukarela. Konsep tersebut menarik, karena mengangkat nilai-nilai budaya lokal untuk mendekontruksi tax amnesty. Namun, konsep tersebut tak ubahnya hanya dalam bentuk konsep atau bersifat teoritis. Pada saat peneliti mewawancarai Bapak Heru, peneliti mengungkap adanya konsep kepatuhan yang dikemas dalam bingkai sukarela. Indonesia, sebenarnya mampu untuk membangun kepatuhan sukarela, hanya saja pemerintah dalam hal ini Direktorat Jenderal Pajak (DJP) yang perlu

\{membenahi\} terlebih dahulu melalui perbaikan sarana prasarana maupun Sumber

Daya Manusia (SDM). Baru-baru ini DJP sudah memperbaiki sarana yang berbasis IT seperti: E-Faktur, e-Filling, E-Billing,dan sebagainya. Bapak Heru menuturkan bahwa tax amnesty adalah suatu kebijakan yang tidak diperlukan dalam hal membangun kepatuhan wajib pajak, justru menjadi kebijakan yang \{membebani masyarakat\}. Seperti pernyataan berikut : 
"Mau nggak mau perlu ada satu ide ya itu tadi dengan jalan melakukan extensifikasi dan intensifikasi. Cuma itu tadi harusnya kebijakan tidak membebani masyarakat. Karena masyarakat sudah banyak tanggunganya. Pajak itu bisa pajak pusat maupun pajak daerah. Bisa restribusi juga ini tapi masih di bebani lagi dengan TA. Mungkin pemerintah perlu kebijakan kebijakan yang friendly lah. Artinya apa ya contohnya dikenai pemajakan yang sifatnya langsung. Lah ini dalam rangka untuk transparansi. Mereka beranggapan bahwa duit saya ternyata dikorupsi itu loh."

Pada tataran ini kesadaran "Aku" dalam hal kebijakan pemerintah yang banyak memberatkan masyarakat. Menurut Bapak Heru perubahan yang paling prinsip adalah merubah definisi pajak itu sendiri. Definisi pajak yang mulanya adalah iuran untuk kontraprestasi yang tidak langsung menjadi iuran yang \{sifatnya langsung\} dan \{bersentuhan\} dengan keseharian dari masyarakat. Refleksi kesadaran "Aku" pada titik ini adalah kepatuhan wajib pajak dapat tercipta ketika iuran wajib pajak yang dibayarkan dapat memberikan kontraprestasi langsung kepada si pembayar. Sebagai contoh, pembayar yang secara tertib memenuhi kewajiban perpajakannya akan menuai manfaatnya seperti Bantuan Langsung Tunai (BLT), Operasi pasar maupun CSR oleh perusahaan.

"Transparansi iu ndak harus iki loh laporane. Oh penerimaan segini. Kontraprestasi imbal baliknya itu langsung. Wujud nyata ini loh peran sertamu masyarakat wujudnya kayak gini. Mungkin dengan CSR perusahaan kan ada CSR. Nah mungkin pemerintah CSR. Mungkin kayak BLT itu atau operasi pasar. Ya ndak taulah pokonya yang sifatnya langsung. Langsung bersentuhan dengan keseharian dari masyarakat."

Bapak Heru menyebutkan bahwa kontraprestasi atas pembayaran pajak yang tidak langsung inilah yang menyebabkan pajak dipandang oleh wajib pajak sebagai hal yang membebani dan merugikan. Selain merubah definisi pajak dengan adanya unsur kontraprestasi langsung, Bapak Heru juga menyebut bahwa perlu adanya \{transparansi $\}$ antara wajib pajak dan pemerintah. Transaparansi dalam hal ini bukan berarti berupa tumpukan laporan yang disampaikan kepada wajib pajak. Namun, melalui suatu bentuk sikap amanah. Amanah yang dimaksud adalah amanah Undang-Undang Dasar yang secara struktur berada diatas Undang-Undang perpajakan. Amanah dalam hal ini adalah untuk mencapai sebesar-besarnya kemakmuran rakyat. Sehingga, dapat merubah rasa pesimis masyarakat terhadap apa yang dikontribusikan selama ini. Hal ini yang kemudian dapat menjadikan masyarakat sadar akan pajak. Peneliti menyimpulkan bahwa kunci untuk menciptakan kepatuhan sukarela adalah kesadaran dan adanya kontribusi negara kepada wajib pajak secara secara langsung. Ketika wajib pajak sadar akan pentingnya pajak bagi pembangunan negara, maka wajib pajak akan memiliki rasa peduli. Dari kepedulian tersebut nantinya wajib pajak akan patuh secara sukarela. Selain bermakna keterpaksaan wajib pajak, Bapak Heru menyebut adanya kemiripan antara tax amnesty dengan kebijakan baru pasca tax amnesty atau dikenal dengan istilah PAS FINAL (Pernyataan Aset Sukarela Final). PAS FINAL menurut Bapak Heru hanya \{istilah\} saja yang menggantikan tax amnesty. Namun, pada konteksnya hampir sama. Dalam hal ini, sama-sama di berikan \{kesempatan sekali lagi\} bahkan untuk yang kedua kalinya. Kesempatan yang dimaksud berupa ampunan-ampunan dengan membayar tarif yang telah ditentukan. Bapak Heru membandingkan ketika tax amnesty ada, maka konsekuemsi dari pengungkapan harta yang belum dilaporkan adalah uang tebusan. Sedangkan pada PAS FINAL maka yang ada tarif pajak final atau pasal 4 ayat 2. Namun, pada tataran ini Bapak Heru menilai bahwa hadirnya PAS FINAL dilatarbelakangi oleh kegagalan tax amnesty sebelumnya dalam hal realisasi yang kurang dari apa yang telah ditargetkan. Terlebih, DJP mengetahui bahwa masih banyak wajib pajak yang enggan melaporkan pajaknya. Seperti pernyataan Bapak Heru :

"Walaupun mungkin masih ada yang tidak melaporkan hartanya itu $100 \%$ saya yakin pasti ada. Karena siapapun, saya, anda, apalagi wajib pajak wajib pajak yang buesar-buesar yang kelas kakap itu kalau menyangkut harta, menyangkut penghasilan dan itu nanti dikaitkan dengan pajak, itu tidak akan ada yang melaporkan keadaan yang sebenernya. Pasti ada yang tidak dilaporkan. Karena pajak kembali ke definisinya. Pajak itu adalah pungutan yang sifatnya dipaksa."

Menurut penuturan Bapak Heru bahwa \{Definisi \} pajak yang sifatnya memaksa inilah yang kemudian membuat harta maupun utang dari wajib pajak itu pasti ada yang \{tidak dilaporkan\} sesuai dengan kondisi yang sebenarnya. Adanya kecenderungan untuk menghindari. Meskipun, pemerintah sendiri membuat pengakuan bahwa pasca tax amnesty tidak ada kebijakan tax amnesty jilid 2. Bapak Heru 
malah menilai kemunculan PAS FINAL merupakan jurus baru dari pemerintah untuk memberikan kesempatan bagi wajib pajak yang masih belum melaporkan hartanya. Mengingat sistem pajak di Indonesia yang berkiblat pada Self Assesment System, justru menimbulkan dilema. Dilema yang terjadi adalah pemerintah sangat bergantung pada kepatuhan wajib pajak karena dengan adanya sistem ini maka wajib pajak diberi kebebasan untuk menghitung dan melaporkan sendiri kewajiban perpajakannya. Namun, kondisi kepatuhan wajib pajak malah bertolak belakang dengan tujuan di terapkannya Self Assesment System. Karena kebebasan yang diberikan inilah cenderung membuka celah bagi wajib pajak untuk memiliki kesempatan dalam bertindak secara tidak semestinya dalam memenuhi kewajiban perpajakannya. Seperti, wajib pajak dapat membuat laporan ganda dan melaporkan penghasilan yang lebih kecil untuk membayar pajak rendah atau bahkan wajib pajak melakukan tindakan pengemplangan pajak (tidak membayar pajak) padahal memiliki penghasilan atau tambahan kekayaan. Kondisi seperti ini yang menjadi salah satu alasan diberlakukannya undangundang pengampunan pajak atau tax amnesty. Berbagai macam kebijakan pasca tax amnety semestinya tidak perlu di gulirkan dengan mendewakan kata "pemakluman" sebagai salah satu wujud langkah penegakan hukum. Langkah ini kontradiktif dengan tujuan dari pemerintah, hal ini justru malah melemahkan respon wajib pajak dan merasa diperlakukan tidak adil meskipun telah mengikuti tax amnesty.

Selain itu, Bapak Heru melanjutkan bahwa banyak wajib pajak yang tidak paham dengan tax amnesty. Banyak sekali poin-poin, klausul, detail dan teknis dalam aturan perpajakan yang terkadang membingungkan dan sulit dipahami. Bahkan, tidak jarang ada peraturan yang sifatnya abu-abu dan multi tafsir. Sebagai contoh kebijakan tax amnesty. Pelaksanaan sosialisasi yang masih kurang jelas dan membingungkan wajib pajak dengan perbedaan penafsiran oleh masing-masing petugas membuat pelaksanaan tax amnesty masih terkendala (Istighfarin,2017).

Wajib pajak mengikuti tax amnesty karena \{euforia\} dan \{ikut-ikutan\}. Artinya masih banyak wajib pajak yang belum memahami mengenai mekanisme tax amnesty. Meskipun DJP sudah melakukan sosialisasi bukan berarti wajib pajak memahami tax amnesty dengan mata terbuka. Seperti ungkapan beliau:

"Banyak WP yang nggak ngerti TA iku opo. Walaupun KPP itu sudah melakukan sosialisasi tapi banyak kalau ketemu face to face itu banyak nggak ngerti TA maksude opo. Banyak yang gitu. Jadi mereka itu yo wes ikut-ikutan TA. Padahal belum tentu ini kategori pajak yang ikut TA."

Menurut Bapak Heru, wajib pajak mengikuti tax amnesty itu hanya untuk membersihkan nama baiknya saja. "Supaya diarani ya patuh nggak dicap WP bandel atau WP sing gak patuh", tandas beliau. Tetapi, yang mengikuti tax amnesty justru bukan wajib pajak kelas kakap yang memiliki harta sekian besarnya malah banyak yang berasal dari wajib pajak kecil. Refleksi Kesadaran "Aku" berada pada realitas bahwa tax amnesty hanya sebagai ajang untuk pembersihan nama baik untuk bisa menyandang gelar " wajib pajak patuh".

\section{Simpulan}

Berdasarkan uraian penjelasan yang telah disampaikan di atas, maka kesimpulan dari penelitian ini adalah sebagai berikut :

1. Realitas kepatuhan pasca tax amnesy menurut wajib pajak adalah suatu tarif matematis kepatuhan. Tarif yang dimaksud adalah uang tebusan nilainya lebih kecil dari harta yang dilaporkan untuk memperoleh ampunan pajak. Kepatuhan terurai ketika "Aku" mengungkap bahwa ada jaminan dibebaskannya dari pemeriksaan pajak, khususnya tahun 2015 kebawah. Selain itu, tax amnesty adalah salah satu bentuk siasat untuk "menghindari pengawasan".

2. Realitas kepatuhan pasca tax amnesy menurut konsultan pajak adalah dilema antara takut dan patuh. Tax amnesty tidak secara otomatis meningkatkan kepatuhan wajib pajak. Adanya unsur penekanan maupun ancaman yang dilakukan kepada wajib pajak dalam mengikuti program tax amnesty mengakibatkan wajib pajak menjadi ketakutan dan terpaksa. Tidak banyak wajib pajak yang memahami tax amnesty.

\section{Daftar Pustaka}


Bagiyada, I Made dan I Nyoman Darmayasa. 2016. Tax Amnesty Upaya Membangun Kepatuhan Sukarela. Simposium Nasional Akuntansi Vokasi V. Makasar.

Creswell, John. W. 2015. Penelitian Kualitatif \& Desain Riset, Memilih Di Antara Lima Pendekatan. Yogyakarta : Pustaka Pelajar.

Darmayasa, I. N. dan Yuyung R.A. 2016. Catur Purusa Artha Lensa Dekonstruksi Definisi Pajak Yang Berkeadilan. Simposisum Nasional Masyarakat Multiparadigma (MAMI) dan Pertemuan Masyarakat Akuntansi Multiparadigma Indonesia Nasional (TEMAN) 4. Jakarta : 14-15 April 2016.

Darmayasa , I. N dan Yuyung R.A. 2016. Diskursus Tax Amnesty melalui RUU Pengampunan Nasional. Journal of Auditing, Finance, and Forensic Accounting. Volume 4, Oktober 2016 : 111-120.

Diamastuti .E. 2012. Ke (Tidak) Patuhan Wajib Pajak: Potret Asli Self Assesment System. Jurnal Ekonomi dan Keuangan Akreditasi (EKUITAS). Volume 20, Nomor 3, September 2016 : 280304.

Fidiana dan Nabila Istighfarin. 2017. Implementasi Tax Amnesty dari Perspektif Masyarakat Pajak. Jurnal Ilmu dan Riset Akuntansi. Volume 6, Nomor 2, Februari 2017 : 564-576.

Hasbiansyah, O. 2008. Pendekatan Fenomenologi : Pengantar Praktik Penelitian dalam Ilmu Sosial dan Komunikasi. MediaTor Jurnal Komunikasi, 9 (1), 163-180.

Kamayanti, Ari. 2016. Metodologi Penelitian Kualitatif Akuntansi Pengantar Religiositas Keilmuan. Jakarta : Yayasan Rumah Peneleh.

Kusuma, Hendra. 2017. Tax Amnesty Dianggap Gagal, Ini Pembelaan Ditjen Pajak. www.detik.com. Diakses pada tanggal 11 Desember 2017.

Kusuma Lila dan Maya Widyana. 2018. Kebijakan Tax Amnesty: Suatu Peninjauan dalam Perspektif Etika Deontologi Sebagai Bentuk Pilihan Wajib Pajak dalam Melaksanakan Kewajiban Perpajakan. Jurnal Akuntansi dan Pajak. Januari 2018 : 204-214.

Moleong, L. Y. 2005. Metodologi Penelitian Kualitatif Edisi Revisi. Bandung: PT Penerbit Remaja Rosdakarya.

Ngadiman dan Daniel Huslin. 2015. Pengaruh Sunset Policy, Tax Amnesty, dan Sanksi Pajak terhadap Kepatuhan Wajib Pajak. Jurnal Akuntansi Volume XIX.

Primadhyta, Safyra. 2017. CORE : Hasil Dari Tax Amnesty Jauh Dari Ekspektasi. www.cnnindonesia.com. Diakses pada tanggal 8 Desember 2017.

Ragimun. 2016. Analisis Implementasi Pengampunan Pajak (Tax Amnesty) di Indonesia. Badan Kebijakan Fiskal Kemenkeu RI.

Sakti .N.W dan Asrul Hidayat. 2016. Tax Amnesty itu Mudah. Jakarta : Visimedia.

Setyaningsih dan Antin Okfitasari. 2016. Mengapa Wajib Pajak Mengikuti Tax Amnesty (Studi Kasus Di Solo). Jurnal Ekonomi dan Keuangan Akreditasi DIKTI. Volume 20, Nomor 4, Desember $2016: 415-433$. 
Sulistiowati, Syaiful

Sukmana,Yoga. 2017. Rasio Pajak Masih Rendah, Sri Mulyani Heran. www.kompas.com. Diakses pada tanggal 4 Desember 2017.

Sujarweni, V. Wiratna. 2015. Metodologi Penelitian Bisnis dan Ekonomi. Yogyakarta : PUSTAKABARUPRESS.

Tambunan, R. 2015. Mengupas Sunset Policy \& Tax Amnesty, Senjata Kejar Target Pajak. 